\title{
THE CORRELATION BETWEEN GRAMMAR COMPETENCY AND SPEAKING ABILITY OF THE EIGHTH GRADE STUDENTS IN SMPN 1 PALU
}

\author{
Aldi Saputra \\ Nurasmawati \\ Yuni Amelia \\ English Tadris Study Program, Faculty of Tarbiyah and Teacher Training \\ State Islamic University (UIN) Datokarama Palu \\ Email: aldisyahputrasyahdin@gmail.com
}

\begin{abstract}
This research was motivated by the problems experienced by some of the eighth grade students in SMPN 1 Palu. The students still had some difficulties when expressing their ideas or feelings by using English. They had various reasons for this. Most of them said that grammar is one of the causes of their difficulties in speaking English.

This research was a correlational design, the technique of collecting data using test. There were two kinds of test such as written test and oral test as the research instrument. The written test was used to measure students' grammar competency and oral test was used to measure students' speaking ability. The researcher used Pearson Product Moment Correlation in analyzing the data by using SPSS program 26 version.

Based on the results of the correlation analysis between the students' grammar competency and the students speaking ability, the $r$ value was obtained at 0.407 ( $r>0.361$ ) with $\mathrm{p}=0.023(\mathrm{p}<0.05)$ indicating that there was a significant positive correlation between students' grammar competency and students' speaking ability. This supported the alternative hypothesis to be accepted and the null hypothesis to be rejected. It could be concluded that there was a correlation between grammar competency and speaking ability at the eighth grade students of SMPN 1 Palu in the academic year of 2020/2021.
\end{abstract}

Keywords: correlation, grammar competency, and speaking ability. 


\section{Datokarama English Education Journal Vol.2 No. 2, 2021}

\section{INTRODUCTION}

This chapter presents the basic information of this research. It emphasizes things that become the background of this research then this research is carried out. This chapter is divided into some headings such as the background of the research, limitation of the problem, problem statement, the objective of the research, the significances of the research and the definition of the terms.

\section{A. Background of the Research.}

English is defined as an international language where this language is used as the main of communication tool for all of people to interact each other. English has been taught as a foreign language since junior high school as a standard of curriculum in Indonesia(curriculum2013). There are four skills in English that are taught to the students, and they should master all of those skills.

Speaking is one of the four skills in English, and it is a process which people share about their opinions, feelings, and messages by using language as the media. It is the most important one because through oral communication, we can maintain our relationship with other people. In communication, there are two or more people who interact each other and it needs a better ability to speak so that good communication can be established between the communicant and the communicator. By doing interaction with the other people, we can get a lot of information and sharing ideas to the others.

Speaking ability is one of the skills that is wanted to be mastered by people in learning certain language including English. However, many English learners think speaking is a difficult skill that should be mastered when we learn about English as a foreign language. It is different with another skill such as listening, reading and writing. The reason of speaking is different from other skills, generally the people you are talking to will also be waiting for you to talk right then and at the same time you will not be able to correct or edit what you have been saying. This will be a measure of people success in language learning compared to the other skills such as listening, reading and writing. ${ }^{1}$

When students write, they have time to sit and think about what they will write, and how they will write it. But in speaking, they have to respond more quickly, this can make students feel afraid to say anything. ${ }^{2}$ As believed by Brown, man could be stated as successful in learning certain language if they could communicate with the other people in oral communication or spoken language. It means speaking is not the easy skill that has to be mastered by students. ${ }^{3}$

In daily life, people need more time to communication. The most dominating forms of communication in social life is an oral communication. People need communication with others in providing information, obtain information, or even entertaining. In reality, the only man is capable of communicating verbally. ${ }^{4}$

In oral communication, generally all the English learners have the same

1 Yolanda Arlyansi, "The Correlation Between English Grammar Competency and Speaking Skill of The Eleventh Grade Students at Senior High School 1 Teluk Kuantan" (English Education Department, State Islamic University of Sultan Syarif Kasim Riau, PekanBaru, 2018), 1

2 Joanna Baker and Heather Westrup, Essential Speaking Skills: A handbook for English Language Teachers (New York: Continuum, 2003), 16.

${ }^{3} \mathrm{H}$. Douglas Brown, Principles of Language Learning and Teaching (3rd Ed) (Englewood Cliffs: Prentice Hall, 2001), 267.

4 Nur Asmawati, "Model of English learning Based on Collaborative Theory to improve Indonesian' Spoken Communication Ability" Vol. 4, No. 2 (Makassar: ETERNAL (English Teaching Learning and Research Journal, 2018), 255 


\section{Datokarama English Education Journal Vol.2 No. 2, 2021}

objective that is to speak fluently and accurately. The fluency is the ability to convey ideas in a way that can be understood by people imply the speaker comprehend show to use the language itself. And then the accuracy is the ability to choose vocabulary and arrange it with the correct word structure so that the listener is able to grasp the meaning and understand the important essence of conveying this information. Since accuracy refers to completeness of language structure, it focuses on vocabulary, pronunciation and most importantly grammar.

Many students find it difficult to respond if the teacher asks them to say something in a foreign language. They may have little idea about what to say, they may not know the words to use, or they may not be sure how to use the grammar. ${ }^{5}$ Grammar is the whole system and it is a structure of every language in general. Without good and correct grammar skills, a person will find it difficult to convey ideas precisely so that the ideas cannot be more easily understood by others.

Referring to Thornburry, grammar is a kind of 'sentence-making machine'; grammar is a fundamental or a basic knowledge in every language. ${ }^{6}$ Thus without grammar competency, people will not be able to communicate well or to deliver a message to the listeners. From that statement, it can be concluded if someone has better grammar, it will influence his capability in speaking. It is very important to realize that even though people can speak English, if they do not understand about grammar it can be said they do not communicate well.

5 Joanna Baker and Heather Westrup, Essential Speaking Skills: A handbook for English Language Teachers (New York: Continuum, 2003), 16.

6 Scott Thornbury, How to Teach Grammar (Edinburgh: Pearson education limited, 1999), 15.
Based on the research that had been conducted by Dian Islamiati in Department of English Education Faculty of Teaching and Educational Science of Swadaya Gunung Jati University, many Indonesian learners have difficulties when they are asked to speak English. The big problem is they are afraid to start speaking because of their limitations in grammar. They feel grammar is the big obstacle for them to start speaking English. ${ }^{7}$ Another research that had been conducted by Silfani at the eleventh grade students of SMA Kristen Barana also showed that some of the learners did not use the proper grammar when they spoke in English. Almost all of the students are good in speaking because they have a teacher that especially teaches in speaking skill. In contrary, in spite of their good speaking, they sometimes also make mistakes in speaking English, especially their grammatical structure, which made some of their friends cannot understand what they mean. ${ }^{8}$

In October 2020, the researcher has found the similar problems through observation from the students at SMPN 1 Palu. Actually they understood some questions that had been asked by the researcher but they looked anxious. As the result, they were not confident in answering the questions. According to them, they felt afraid to convey their ideas. Some of them said the reason is because they do not have enough vocabulary. Others said that they do not know how to pronounce the words, and most of them also said that they feel hesitate in using grammatical structure whether it has been correct or not.

${ }^{7}$ Dian Islamiati, "The Correlation between Students' Grammar Knowledge and Their Speaking Ability" (English Education, Swadaya Gunung Jati University, Cirebon, n.d.)

${ }^{8}$ Silfani "The Correlation between Students' Speaking Ability and the Mastery of Grammar at the Eleventh Grade Students of SMA Kristen Barana" (English Education Study Program, Christian University of Indonesia Toraja, n.d.) 


\section{Datokarama English Education Journal Vol.2 No. 2, 2021}

Explicit awareness of grammatical structure probably helps children to expand their competency to include many grammatical patterns which are needed in adult life but not found in children's casual conversation, and a shared meta language allows teachers and pupils to communicate about their performance and to explore complex links such as those between grammatical structures and genres. The importance of grammar is also due to the fact that it is because of grammar of the language that makes it possible for us to talk about language. The middle school students from China believe that grammar is very important and necessary. There are several reasons for its importance and necessity, one of which is that they have few opportunities and little time to get enough input inside and outside the class. ${ }^{9}$

From some of the theories above, it can be concluded that grammar is very necessary to be concerned in a speaking process; we have to know the way how to set some words into sentences and then use them in communication to make other people understand what we mean. Thus, by considering those aspects, the researcher is interested to do this research with the title The Correlation between Grammar Competency and Speaking Ability of the Eight Grade Students in SMPN 1 Palu.

\section{B. Limitation of the Problem}

Grammar competency and speaking skill cover many problems and it is important to observe it. Therefore, the researcher limits this research only to recognize grammatical structure in simple present tense and self-introduction orally for speaking skill.

\section{Problem Statement}

Referring to the background of this research and based on the limitation of the

9 Shengmei Wang, "The Significance of English Grammar to Middle School Students in China" (Finland: Academy Publisher, 2010), 313 problem, thus problem statement is formulated as follow: "Is there any correlation between English grammar competency and speaking ability of the Eighth Grade Students in SMPN 1 Palu?"

\section{The Objective of the Research}

From the problem statement, the objective of this research is as follow: "To find out whether there is a correlation between English grammar competency and speaking ability of the eighth grade students in SMPN 1 Palu"

\section{E. The Significance of the Research}

The significances of this research are as follows:

1. Students are expected to be able to realize that grammar has a very important role in speaking ability.

2. This research is also expected to provide advantages for English teachers to understand and develop their strategies in teaching and learning.

3. This research can be an additional reference for future researchers who will conduct research in the same case or the same topic.

4. Significant contributions to the field of education are also expected to be achieved by this research especially for the growth of academic research.

\section{F. Definition of the Terms}

1. Correlation is one of the diagnostic techniques in statistics that is used to look for an association between two or more quantitative variables.

2. Grammar competency is the ability to combine words and change the form and position of words in producing sentences in a particular language.

3. Speaking ability is the capacity of human to convey their views or 


\section{Datokarama English Education Journal Vol.2 No. 2, 2021}

point of view and mindsets verbally to a person or group, either personally or from a distance.

\section{REVIEW OF RELATED LITERATURE}

The theoretical framework in this research is based on the concepts, theories, as well as some of the previous research on the grammar competency and speaking skill which will be discussed below.

\section{A. The Previous Research}

Previous research is a literature studies that has a common theme which researchers later use to compare and find areas of research that have not been researched by the previous researchers.

There are two previous researches with the similar topic that the researcher has already found and it is relate with his research. The first research is from Agus Priyanto and Lies Amin L, they conducted a research with title "The Correlation between English Grammar Competency and Speaking Fluency of Eleventh Grade Students in SMAN 1 Sidoarjo "The objective of this research referring to the research problem is to find out whether there is a significant correlation between grammar competency and speaking fluency of eleventh grade students in SMAN 1 Sidoarjo. The design of the research is correlational research. Based on the result of the test then they used the Pearson product moment formula to calculated the data to know is there any correlation between two variable of the research and from the calculation using the Pearson Product Moment formula, it was discovered that the $\mathrm{r}$ value was 0.44 . The value of the r-table with 5\% level of significance and 48 degree of freedom is 0.279 . Thus, the observed $r$ value is higher than the r-table which means the correlation is significant and they conclude that there is a correlation between English grammar competency and speaking fluency of eleventh grade students in SMAN 1 Sidoarjo. Although it does not signify a causal relationship, it can still be argued that good grammatical competency tends to run with good speaking fluency and somewhat. ${ }^{1}$

The second research is conducted by Anwar Rahman and Rafista Deviyanti entitled "The Correlation between Student's Motivation and Their English Speaking Ability". This research is objective at investigating the correlation between students' motivation and their English speaking ability. This research used ex post facto design. From the result of the research it showed that motivation plays important role in developing competencies in students' self that make them devote efforts to achieve their goals. They would learn more in such way that their English develop snicer and they are capable to state their perception into the target language, specifically in speaking. ${ }^{2}$

From the both research above, it can be concluded that there are some aspects that can influence students speaking skill. This research has similarities and differences with the previous researches above, the similarity with the first research is the researcher also do research about the correlation of students' grammar competency by using a correlational research design and the difference is the first researcher focused on speaking fluency while the researcher focus on the two components of students' speaking ability specifically grammar and vocabulary. Then the difference with the second researcher is they did not focused

${ }^{1}$ Agus Priyanto and Lies Amin L "The Correlation Between English Grammar Competency and Speaking Fluency of Eleventh Grade Students in SMAN 1 Sidoarjo" (English Education, Surabaya State University, n.p., n.d) 3-6

2 Anwar Rahman and Rafista Deviyanti

"The Correlation Between Student's Motivation and Their English Speaking Ability ".Jurnal ilmiah esai, Vol. 6, No. 1 (January 2012). 


\section{Datokarama English Education Journal Vol.2 No. 2, 2021}

on grammar competency but focus on students' motivation and their research used ex post facto design. Beside that the previous researchers did the research in senior high school level while the researcher will do this research in Junior high school level.

\section{B. Literature Review}

1. The Explanation of Grammar.

According to Dr. Lowth "Grammar is the art of rightly expressing our thoughts by words " It is, in spite of, the area of grammar, to guide us not only in the expression of our own thoughts, but also in our understanding of thoughts, and our interpretations of other people's words. ${ }^{3}$ Hence, too, the art of reading is actually part of grammar; because it's just understanding art and speaking properly what we have before us on paper. Nugent has accordingly given another definition about grammar itself, as follow: "Grammar is the art of writing, reading, and speaking a language by procedures."

The grammar is used to interpret the analysis of language systems, and the study of grammar is not only considers important features of language learning, but is sufficient for learners to master other languages. Grammar is very important to produce a language because without getting grammar, learners cannot use the language properly. ${ }^{5}$ Hossein Nassaji stated that, Thousands of years, grammar was central to language pedagogy. ${ }^{6}$

Grammar still gives us how to use words: that is to say, it teaches us how to use them in the right way, to choose which words should be placed. We must be familiar with certain principles and rules

\footnotetext{
${ }^{3}$ Goold Brown, The Grammar of English Grammars (Project Gutenberg, 2004), 41.

${ }^{4}$ Ibid.

5 James Purpura. Assessing Grammar, (Cambridge: Cambridge University Press, 2004), 1.

${ }^{6}$ Hossien Nassaji and Sandra Fotos, Teaching ESL/EFL : listening and speaking (New York, Routledge, 2009), 2.
}

which constitute a set of grammar. This means that without grammar our sentences are incomplete, sometimes listeners find it very difficult to understand what we mean. ${ }^{7}$

Grammar presents our idea in communication. In order to our message can be more understood by other people. There are four items that include in grammar such as syntax (word composition), morphology (word composition), and Phonology (sound) due to in communication the grammar is absolutely necessary. Impulsively we have to be competent in comprehending about grammar, since the grammar itself controllers us in constructing sentences and as well as a central in teaching and learning of languages. ${ }^{8}$

From some of definitions above it can be concluded that grammar is very important to be mastered by the user of language as the result we can set words or sentences by using a correct structure and make it meaningful so it can be understood by the other people.

\section{a. The explanation of simple present tense.}

In this research the researcher will focus on Simple Present Tense only. Simple Present Tense is a formula that is used to state an action that always happen or repeated in our daily activity or habitual activity. This tense also used to state about the truth.

\section{1) Sentence patterns}

(+) $\mathrm{S}+\mathrm{V}-1(\mathrm{~s} / \mathrm{es})+\mathrm{O}+$ adverb of time

${ }^{7}$ David Nunan, Language Teaching Methodology, (Cambridge: Cambridge University Press, 1991), 296.

${ }^{8}$ Yolanda Arlyansi, “The Correlation Between English Grammar Competency and Speaking Skill of The Eleventh Grade Students at Senior High School 1 Teluk Kuantan"(English Education Department, State Islamic University of Sultan Syarif Kasim Riau, PekanBaru, 2018), 14 


\section{Datokarama English Education Journal Vol.2 No. 2, 2021}

(-) $\mathrm{S}+$ do / does + not $+\mathrm{V}-1+\mathrm{O}+$ adverb of time

(?) Do / does $+\mathrm{S}+\mathrm{V}-1+\mathrm{O}+$ adverb of time

Example:

(+) You study English at MEC every day.

(-) You don't study English at MEC every day.

(?) Do you study English at MEC every day?

a) If the subject is the third person sentence is single (the third person singular-she / he / it), the verb must be added with an "s" or"es" in a positive statement.

Example:

- Mary usually goes swimming on Saturday morning.

- Mother always serves our breakfast before we go to school.

- My brother likes playing tennis on Sunday morning.

b) The "s" ending in the verb

Generally, verbs are added with the "s" ending if the subject is the third person singular (he / she / it).

Example:

- I work five days a week.

- We play tennis every Sunday.

- The boys play in the garden.

- She works five days a week.

- Father takes a train to go to office.

- A mouse eats my food every morning

c) The suffix "ice" used with a verb whose ending letter "s, ch, sh, $x, o^{\prime}$, if the subject is third person singular. Meanwhile, the verb whose letter ends is " $y$ " and is preceded capital letters, $y$ first replaced with " $i$ " then added "ice".

Example:
- I pass the house.

- You watch television.

- He passes the house.

- We wash our clothes.

- John goes to office.

- They go to office.

- She washes her clothes.

- Is tudy English.

- She watches television.

- He studies English.

d) The negative sentence

It is formed with put the "don't / don'ts or doesn't / doesn't" after sentence subject. "Doesn't" be used in the third person singular (he doesn't, she doesn't, it doesn't), while "don't" is used for other than the third person singular (I don't, you don't, we don't, they don't).

Example:

- You don't go swimming on Monday.

- We don't work on Saturday.

- I don't work at the aircraft factory.

- He doesn't work on Saturday.

- My brother doesn't play football every day.

- John doesn't work at the aircraft company.

e) Interrogative

Interrogative sentences are formed by placing the Help word "do or does" in front of the sentence. "Does" used for the third person singular (he, she, it), whereas "do" is used for anything other than the third person singular (I, you, we, they). "Do / does" in an interrogative sentence means "what" and the verb no longer uses the "s / es" suffix although the subject of the sentence is in the third person singular

Example:

- Do you always go to office by train?

- Do they go swimming every Sunday?

- Do the boys like this film?

- Does your brother work for bank Mandiri?

- Does he go swimming every Sunday?

- Does the boy like this film? 


\section{Datokarama English Education Journal Vol.2 No. 2, 2021}

f) The suitability of the subject and auxiliary verbs in this tense isas follows:

DO is used by subject I, you, we, and they.

DOES is used by the subjects she, he, and it.

2) Use

a) Simple present is used to show an event, events, activities that occur repeatedly, or are a habit (habit).

Example:

- I leave for office at 6 every morning.

- My father works five days a week.

- Father always drinks tea in the afternoon.

b) Simple present is also used to show a fact (fact) or something which is a general truth (general truth).

Example:

- The River Nile flows into Mediterranean.

- Jet engines make a lot of noise.

- Vegetarians don't eat meat and fish.

c) Simple present is also used to show something will happen in the future, if we are discuss a schedule, program, and others.

Example:

- The second train leaves at 10 a.m.

- The football match starts at 4 p.m. tomorrow.

- $\quad$ The second film begins at 7 p.m.

3) Adverb of time

a) Adverb of frequency

Always, Usually, generally, ever, Sometimes, occasionally, never, seldom

b) Adverb of quantity

Once, once a day, once a week, Twice, three times, every ${ }^{9}$

${ }^{9}$ Erwin Hari Kurniawan, Basic English Grammar (Kediri: SMA3 Press, 2010), 2-6.
2. The Explanation of Grammar Competency.

Competency is described as understanding of Knowledge in using the grammatical resources of a language. It is the capacity to recognize and express meaning over generations and the recognition of well-formed sentences in the spirit of these principles (as opposed to memorization and reproduction) them as fixed formula). ${ }^{10}$ Grammar competency is the ability to develop and produce grammatical structures that are typical of a language and effectively communicate. Grammar competency enables speakers to use and understand the structure of the English language accurately, which contributes to their fluency. ${ }^{11}$

Moreover, Chomsky explained grammar competency as theoretic and concrete knowledge of a partial number of grammatical rules, which permit making an infinite number of accurate sentences. ${ }^{12}$ Additionally, Lock talk about that grammar competency was learned by the approach of the rule plus, drilling methodology, typical of audio lingual or traditional grammar methods. ${ }^{13}$ In conclusion grammar competency is someone's intelligence in science of learning about rules that manage the using of language which is if the learners have a good grammar competency so it will be easier to understand how to construct a sentence effectively to convey expressions.

\footnotetext{
${ }^{10}$ Marco Tulio Artunduaga Cuellar, Process Writing and the Development of Grammatical Competency.(How Journal, 2013), 14.

${ }^{11}$ Yolanda Arlyansi, "The Correlation Between English Grammar Competency and Speaking Skill of The Eleventh Grade Students at Senior High School 1 Teluk Kuantan"(English Education Department, State Islamic University of Sultan Syarif Kasim Riau, PekanBaru, 2018), 14

${ }_{12}$ Noam Chomsky, Aspects of the Theory of Syntax (Cambridge: MIT Press, 1965)

${ }^{13}$ Graham Lock, Functional English Grammar: an Introduction for Second Language Teachers (Cambridge: Cambridge University Press, 1997)
} 


\section{Datokarama English Education Journal Vol.2 No. 2, 2021}

Grammar shows an important part in communication, without mastery of grammar it is impossible to do communication with someone through language. Maxom said that there are thousands of languages in this world and every language have their own grammatical system. In this way students can easily get it wrong when they try to link the words together to construct a sentence in English. ${ }^{14}$ This implies that grammar is the vital part of language, without conquering grammatical system people cannot reach the communication correctly.

\section{Assessing Grammar Competency.}

Assessment relate to a systematic approach for getting information and make inference about students skill which can be done by doing test, interview, observation, questionnaires etc. According to Brown assessment is a current progression that includes a much wider domain. Consequently, assessment is a process to identify student's capacity by using test, interview, observation, questionnaires etc. $^{15}$

When a language teacher reviews multiple assignments for grammar tests, they remember that there are actually many types of assignments that are commonly used in testing and context testing. As we know that this type of holistic task is a collection of tasks to achieve performance and this type of holistic task can then also manage a number of dimensions what we need to remember also is that the assignments we include in the test must match the types of tasks in language use found in the domain of language learning or real life. Traditionally, there have been many attempts to categorize the types of

${ }^{14}$ Michelle Maxom, Teaching English as a Foreign Language for Dummies (Chichester: John Wiley and Sons, Ltd, 2009), 211

${ }^{15} \mathrm{H}$. Douglas Brown, Principles of Language Learning and Teaching(4th Ed) (San Francisco: Addison Wesley Longman, 2004), 4 assignments found in tests. Some have classified tasks in accordance with scoring procedure. Namely, objective test tasks (e.g., true-false tasks) are those in which no expert judgment is needed to assess demonstration with concern to the criteria for correctness. Subjective test tasks (e.g., essays) are those that involve expert judgment to understand and estimate presentation with regard to the criteria for correctness. Assuming that the main objective of a task is to obtain performance, I will converse test asks along with the type of response. I will specify to selected response, limitedproduction and extended-production tasks.

\section{The Explanation of Speaking.}

Speaking is a mechanism to deliver information and idea. This is the first thing or the way to do a contact and communication. Brown states that speaking is an interactive process of constructing meaning that involves producing, receiving, and processing information. ${ }^{17}$ Furthermore, Bailey\& L confirmed that speaking is the productive oral skill. It involves of producing systematic verbal utterances to transport idea. So we can determine to carry meaning, it can be determined by oral skill. ${ }^{18}$ Speaking is a productive skill which is performed orally. It is like any other skill, more complex at first sight and involving more than just articulating a word. ${ }^{19}$ In a language there are several skills, namely listening, speaking, reading and writing. Speaking is the second setting of language skills. This shows that

${ }^{17} \mathrm{H}$. Douglas Brown, Teaching by Principle: An Interactive Approach to Language Pedagogy(New York: Longman, 2001)

18 David Nunan, Practical English Language Teaching ( $1^{\text {st }}$ Ed) (USA: Mc Graw Hill, 2003)

19 Marriam Bashir, "Factor Effecting Students' English Speaking Skills" (British Journal Publishing,

http://www.bjournal.co.uk/BJASS.aspx/2011/Facto $\mathrm{r}$ Effecting Students' English Speaking Skills, 2011), 38 


\section{Datokarama English Education Journal Vol.2 No. 2, 2021}

speaking has a very important social role in people's lives. Language learners realize that speaking involves three areas of knowledge:

a. Mechanics (pronunciation, grammar, and vocabulary): Using the right words in the right order with the accurate pronunciation.

b. Functions (transaction and interaction): Knowing when clarity of message is necessary (transaction/information exchange) and when precise comprehending is not needed (interaction/relationship building).

c. Social and cultural rules and norms (turn-taking, rate of speech, length of pauses between speakers, relative roles of participants): the comprehension how to take into account who is speaking to whom in what situations, about what, and for what motive. ${ }^{20}$

Speaking skill is ability where a person carries out linguistic knowledge in actual communication. Therefore, it can be concluded that speaking is a person's capability to practice words or language to say information in a common voice.

According to Richards speaking is also a suitable mode to make other people be coming more understand with what we mean and say. ${ }^{21}$ Barrass also said that it is a tool for someone in expressing their mind, emotion, and influences or persuades other people to do or to take a certain action. ${ }^{22}$

From the explanation of some experts above it might be understood that speaking is one of the four skills that should be master. This skill has been

\section{${ }^{20}$ Ibid.}

21 Richards Jack and M Richards, Teaching Listening and Speaking from Theory to Practice (New York: Cambridge University Press, 2008), 21.

${ }^{22}$ Robert Barrass, Speaking for yourself (New York: Routledge, 2006), 3. taught to students since in junior high school. They have been taught the way how to convey their idea accurately trough verbal communication and based on the fact for some case there are still many students that experience the difficulties in speaking English.

There are some components that should be concerned in speaking skill by the students, those are:

\section{a. Grammar}

Grammar is required for college students to rearrange an accurate sentence in conversation. The utility of synchronic linguistics is additionally to be told the right thanks to gain experience in a very language in oral and written type.

\section{b. Vocabulary}

Vocabulary suggests that the acceptable diction that is employed in communication. While not having spare vocabulary folks cannot communicate effectively or specific their ideas in each oral and written form. Having restricted vocabulary is additionally a barrier that precludes learners from learning a language. Language lecturers, thus ought to process sizeable information on the way to manage a stimulating classroom in order that the learners will gain an excellent success in their vocabulary learning. While not synchronic linguistics little or no is often sent, without vocabulary nothing is often sent.

\section{c. Pronunciation}

Pronunciation is that the manner for college students to provide clearer language after they speak. It deals with the descriptive linguistics method that refers to the parts of synchronic linguistics created of the weather and principles that verify however sounds vary and pattern in a very language. There square measure 2 options of pronunciation; phonemes and above segmental options. Speakers who 


\section{Datokarama English Education Journal Vol.2 No. 2, 2021}

perpetually mispronounce a spread of phonemes are often very troublesome for a speaker from another language community to grasp.

\section{d. Fluency}

Fluency are often outlined because the ability to talk fluently and accurately. Fluency in speaking is that the objective of the many language learners. Signs of fluency embody a fairly quick speed of speaking and solely a small variety of pauses amd "ums" or "ers". These signs indicate that the speaker doesn't need to pay heaps of your time checking out the language things required to specific the message.

\section{e. Comprehension}

Speaking needs that not solely acumen to provide specific point of language includes synchronic linguistics, pronunciation, vocabulary, and fluency, however conjointly the comprehension of speaker and hearer is considered. Therefore, in speaking can be concluded that the comprehension refers to the speakers' understanding about what are they saying to the listeners in order avoid misunderstanding information; in addition, its function is to make the listeners easily to catch the information from the speaker. $^{23}$

\section{Assessing Speaking Ability}

Assessing speaking skill is the most important aspect in language testing. On the other hand, Speaking is a complex skill among the other skills in English to be evaluated because a lot of criteria should be estimated in speaking such as grammar, vocabulary, pronunciation, fluency and comprehension. Furthermore, the administration of speaking test is little bit complicated for the motive that it will be

${ }^{23}$ Arthur Hughes, Testing for Language Teachers (Second Ed) (Cambridge: Cambridge University Press, 2003), 111. not effective and sufficient to test all elements of speaking in junior high school level.

Consequently, the students are scored just based on two components those are grammar and vocabulary rather than all of components in speaking skill by using the scale rating scores of Brown as follows:

Table 2

The scale rating score of speaking

\begin{tabular}{|c|c|c|}
\hline Aspect & Score & Requirements \\
\hline \multirow{5}{*}{ Grammar } & 1 & $\begin{array}{lr}\text { Errors } & \text { in } \\
\text { grammar } & \text { are } \\
\text { frequent. } & \end{array}$ \\
\hline & 2 & $\begin{array}{l}\text { Can usually } \\
\text { handle } \\
\text { elementary } \\
\text { constructions } \\
\text { quite accurately } \\
\text { but does not have } \\
\text { thorough or } \\
\text { confident control } \\
\text { of the grammar. }\end{array}$ \\
\hline & 3 & $\begin{array}{l}\text { Control of } \\
\text { grammar is good. }\end{array}$ \\
\hline & 4 & $\begin{array}{l}\text { Error in grammar } \\
\text { are quite rate. }\end{array}$ \\
\hline & 5 & $\begin{array}{l}\text { Equivalent to that } \\
\text { of an educated } \\
\text { native speaker. }\end{array}$ \\
\hline Aspect & Score & Requirements \\
\hline \multirow[t]{4}{*}{ Vocabulary } & 1 & $\begin{array}{l}\text { Speaking } \\
\text { vocabulary } \\
\text { inadequate to } \\
\text { express anything } \\
\text { but the most } \\
\text { elementary needs. }\end{array}$ \\
\hline & 2 & $\begin{array}{l}\text { Has speaking } \\
\text { vocabulary } \\
\text { sufficient to } \\
\text { express himself } \\
\text { simply with some } \\
\text { circumlocutions. }\end{array}$ \\
\hline & 3 & $\begin{array}{l}\text { Vocabulary is } \\
\text { broad enough that } \\
\text { he is rarely has to } \\
\text { grope for a word. }\end{array}$ \\
\hline & 4 & $\begin{array}{l}\text { Can understand } \\
\text { and participate in } \\
\text { any conversation } \\
\text { within the range } \\
\text { of his experience }\end{array}$ \\
\hline
\end{tabular}


Datokarama English Education Journal Vol.2 No. 2, 2021

\begin{tabular}{|c|c|c|}
\hline & & $\begin{array}{lr}\text { with a } & \text { high } \\
\text { degree } & \text { of } \\
\text { precision } & \text { of } \\
\text { vocabulary. } & \end{array}$ \\
\hline & 5 & $\begin{array}{l}\text { Speech on all } \\
\text { levels is fully } \\
\text { accepted and } \\
\text { educated native } \\
\text { speakers in all its } \\
\text { features. }\end{array}$ \\
\hline Aspect & Score & Requirements \\
\hline \multirow[t]{5}{*}{ Comprehensions } & 1 & $\begin{array}{lr}\text { Understandsimple } \\
\text { questions } & \text { and } \\
\text { statements } & \text { if } \\
\text { delivered } & \text { with } \\
\text { slowed speech, } \\
\text { repetition or } \\
\text { paraphrase. }\end{array}$ \\
\hline & 2 & $\begin{array}{l}\text { Can get the gist } \\
\text { of most } \\
\text { conversations of } \\
\text { non-technical } \\
\text { subjects (i.e., } \\
\text { topics that require } \\
\text { no specialized } \\
\text { knowledge). }\end{array}$ \\
\hline & 3 & $\begin{array}{l}\text { Comprehension is } \\
\text { quite complete at } \\
\text { a normal rate of } \\
\text { speech. }\end{array}$ \\
\hline & 4 & $\begin{array}{l}\text { Can understand } \\
\text { any conversation } \\
\text { within the range } \\
\text { of his experience. }\end{array}$ \\
\hline & 5 & $\begin{array}{l}\text { Equivalent to that } \\
\text { of an educated } \\
\text { native speaker. }\end{array}$ \\
\hline Aspect & Score & Requirements \\
\hline \multirow{5}{*}{ Pronunciation } & 1 & $\begin{array}{l}\text { Errors in } \\
\text { pronunciation are } \\
\text { frequent. }\end{array}$ \\
\hline & 2 & $\begin{array}{l}\text { Accent } \\
\text { intelligible } \\
\text { though often } \\
\text { quite faulty. }\end{array}$ \\
\hline & 3 & $\begin{array}{l}\text { Errors never } \\
\text { interfere with } \\
\text { understanding } \\
\text { and rarely disturb } \\
\text { the native } \\
\text { speaker. Accent } \\
\text { maybe obviously } \\
\text { foreign. }\end{array}$ \\
\hline & 4 & $\begin{array}{ll}\text { Error } & \text { in } \\
\text { pronunciation } & \text { is } \\
\text { quite rare. } & \\
\end{array}$ \\
\hline & 5 & $\begin{array}{l}\text { Can pronounce } \\
\text { correctly and } \\
\text { articulate clearly. }\end{array}$ \\
\hline Aspect & Score & Requirements \\
\hline
\end{tabular}

\begin{tabular}{|c|c|c|}
\hline \multirow{5}{*}{ Fluency } & 1 & $\begin{array}{l}\text { Frequent } \\
\text { repetition }\end{array}$ \\
\hline & 2 & $\begin{array}{l}\text { Can handle with } \\
\text { confidence but } \\
\text { not with facility. }\end{array}$ \\
\hline & 3 & $\begin{array}{lr}\text { Can } & \text { discuss } \\
\text { particular } & \text { with } \\
\text { interest } & \text { of } \\
\text { competency } & \text { with } \\
\text { reasonable ease. }\end{array}$ \\
\hline & 4 & $\begin{array}{l}\text { Able to use the } \\
\text { language fluently } \\
\text { on all levels } \\
\text { normally } \\
\text { pertinent } \\
\text { profession } \\
\text { needs. }\end{array}$ \\
\hline & 5 & $\begin{array}{l}\text { Has complete } \\
\text { fluency. In the } \\
\text { language such } \\
\text { that his speech is } \\
\text { fully accepted by } \\
\text { educated native } \\
\text { speaker. }{ }^{24}\end{array}$ \\
\hline
\end{tabular}

Accordingly, the researcher will follow the Brown's idea to assess student's speaking test.

\section{The Correlation Between Grammar} Competency and Speaking Ability.

Grammar competency supports mutterers to use and realize English language structures accurately and immediately, which make easy their fluency. ${ }^{25}$ Therefore, grammar competency will influence someone's speaking ability because grammar is one of components in speaking ability which means that when someone has a good grammar competency he can express their opinion, idea and knowledge clearly and freely. When the learners comprehend how to make a sentence structurally, so the meaning will be said easier to catch by the receiver.

24 H. Douglas Brown, Teaching by Principles an Interactive Approach to Language Learners (New York: Addison Wesley Longman, 2001), 380-381.

25 Faezeh Abbaspour, Speaking Competency and Its Components : A Review of Literature (n.p.,2016), 146. 


\section{Datokarama English Education Journal Vol.2 No. 2, 2021}

Commonly the students of English can be assumed success in English if they have better speaking ability and it relates to the vocabulary, fluency, comprehension, pronunciation and especially grammar.

As said by Scacella and Oxford, grammar competency is an umbrella concept that consists of improving expertise in grammar (morphology, syntax), vocabulary, and mechanics with regard to speaking, the word mechanics talk about the basic sounds of letters and syllables, pronunciation of words, intonation, and stress. $^{26}$ People who recognize about grammar can speak expressively more than other people who do not understand about the grammar.

From the statements of some experts above, it might be concluded that grammar has an important role in students' speaking ability and they may relate to each other.

\section{Theoretical Framework.}

Language is very important in our life because language is a communication tool that humans use to express ideas, feelings, and hopes other people in the interactions between them. Talking one important aspect which must be mastered by students in learning English Mastering Speaking is required to facilitate students in conversations in English. The researcher uses the simple present tense and selfintroduction and tells about daily activities. Current conditions are used as material for students' grammar alerts competency and their speaking ability because without simple present tense competency, it will be difficult to talk in current conditions, such as describing ourselves to others.

According to Efrizal, speaking is a way that supports students to communicate which ideas are carried in spoken

26 Robin C. Scarcella \& Rebecca L. Oxford, The tapestry of language learning: The individual in the communicative classroom (Boston, MA: Heinle \& Heinle, 1992), 141. messages. In speaking, speakers must express the language clearly; use good intonation and good grammar structures. ${ }^{27}$ The speakers' character can be seen from the way they speak. Besides, people might call someone as welleducated or uneducated from the way the language spoken. Someone who has good communication, good words intonation, clearly and properly words chosen is often listened well by the hearers. ${ }^{28}$ Thus, the researcher makes a conclusion that grammar competency is very needed to be increased as a result students can structure the sentence properly which can make the listeners more understanding the point of idea that want to be delivered by the speaker.

Grammar is a description of the structure of a language and how units such as words and phrases are combined to produce a good sentence from a language. ${ }^{29}$ Based on the theory and explanation above, the researcher concludes that grammar is one of factors that make students speak English well. If their grammar is great, they will express their thoughts into sentences easily. The results of observations made by the researcher during (PPL) field experience practice conducted at SMPN 1 Palu showed that the students' speaking ability was still low. It happens because of feelings of shame and being afraid of the lack of vocabulary. Some of them who have good enough vocabulary still looked confused in conveying their ideas. Most of them said that they did not understand how

27 Efrizal, D. Improving Students' Speaking through Communicative Language Teaching Method at Mts Ja-alhaq, Sentot Ali Basa Islamic Boarding School of Bengkulu, Indonesia (Bengkulu: State Institute of Islamic Studies (IAIN), 2012), 127

28 Susanti, E. and Amri, Z. "Speaking Board Game to Teach Speaking of Descriptive Text (Paper)" (Padang: Universitas Negeri Padang, 2013), 456

29 David Nunan, Practical English Language Teaching Grammar (New York: McGraw-Hill, 2004) 


\section{Datokarama English Education Journal Vol.2 No. 2, 2021}

to arrange the words correctly which affected their ability to speak.

Thus the researcher assumed that with good grammar competency, students will be able to express their opinions freely and fun. In other words, the relative grammar competency can be used to improve speaking ability.

\section{The Hypothesis}

From all of the theories explained above, the hypothesesa are as follows:

1. Ha: There is a correlation between grammar competency and speaking ability of the eighth grade students in SMPN 1 Palu in the academic year 2020/2021.

2. H0: There is no correlation between grammar competency and speaking ability of the eighth grade students in SMPN 1 Palu in the academic year 2020/2021.

\section{RESEARCH METHODOLOGY}

This chapter relates to the research method which presents Research Design, Data and Data Source, Data Collection, and the last is Data Analysis and interpretation.

\section{A. Research Design.}

The researcher presented the correlation between student's grammar competency and their speaking ability therefore in this research the researcher used a quantitative research to complete the data and the result of the test. Quantitative research is based on the measurement of quantity or amount. It is relevant to phenomena that can be expressed in terms of quantity. ${ }^{1}$ Research design is needed in conducting a research. Research design is required for the reason that it helps the smooth sailing of the several research processes, thereby making

${ }^{1}$ C.R. Khotari, Research Methodology : Methods and Techniques (New Delhi: New Age International (P) Ltd, 2004), 31. research as proficient as feasible yielding maximum information with minimal expenditure of effort, time and money. ${ }^{2} \mathrm{~A}$ research design is the organization of circumstances for gathering and analyzing of data in a manner that purposes to combine relevance to the research objective with economy in way. In actual fact, the research design is the theoretical construction within which research is conducted; it establishes the plan for the collection, measurement and analysis of data. $^{3}$

The research design of this research was correlational design. Creswell states that correlational research design is a method of quantitative research in which investigators measure the degree of association (relationship) between two or more variables or sets of scores. ${ }^{4}$ In this research, the researcher gave some tests to measure the students' grammar competency and the students' speaking ability. The students' English grammar competency as the independent variable and the dependent variable is students' speaking ability.

\section{B. Population and Sample.}

\section{Population}

The population of this research was the eighth grade students of SMP NEGERI 1 Palu in academic year 2020/2021. The total of population was 348 students.

\section{Sample}

In this research, the sampling technique used was cluster random sampling. Cluster random sampling includes grouping the population and then selecting the groups or the clusters rather

\footnotetext{
${ }^{2}$ Ibid., 32

${ }^{3}$ Ibid., 31

4 Cresswell J. W,Educational Research: Planning, Conducting and Evaluating Quantitative and Qualitative Research (New Jersey: Pearson Education, 2008), 60.
} 


\section{Datokarama English Education Journal Vol.2 No. 2, 2021}

than individual elements for inclusion in the sample. ${ }^{5}$ When the respondents agree to participate, they need to be told what exactly they are being asked to do, how much time is needed to contribute and what the utility of the information is that will be given by them. If the samples have an understanding of the research objectives and processes, this will help to build research relationships. ${ }^{6}$

\section{Variable of the Research.}

When one variable depends upon or is a result of the other variable, it is called as a dependent variable, and the variable that is ancestor to the dependent variable is called as an independent variable. Such as, if we state that height depends upon age, then height is a dependent variable and age is an independent variable. In addition to being dependent upon age, height also depends upon the individual's sex, and then height is a dependent variable while age as well as sex is independent variables. In the same way, convenient films and lectures are examples of independent variables, where behavior changes, happening due to the environmental manipulations, are examples of dependent variables. $^{7}$

In this research, there were two variables. The independent variable of the research was the students' grammar competency with $\mathrm{x}$ symbol, and the dependent variable of the research was the students' speaking ability with y symbol.

\section{The Operational Definition of the Variable}

${ }^{5}$ C.R. Khotari, Research Methodology : Methods and Techniques (New Delhi: New Age International (P) Ltd, 2004), 12.

${ }^{6}$ Wahyu Hidayat and Nur Asmawati Lawahid, Metode Fuzzy Delphi Untuk Penelitian Sosial (Bandung: Alfabeta, 2020), 36.

7 C.R. Khotari, Research Methodology : Methods and Techniques (New Delhi: New Age International (P) Ltd, 2004), 30.
The operational definition of variables was used to describe the characteristic of the variable that was investigated by the researcher.

\section{Independent Variable (X)}

Independent variable of the research was the students' grammar competency. It focused on Simple Present Tense.

\section{Dependent Variable (Y)}

Dependent variable of the research was the students' speaking ability which focused on self-introduction and daily activity.

\section{E. The Research Instrument.}

The research instrument is tools that the researcher uses for collecting, measuring, and then analyzing data related to the research. In this research, the researcher used test as the research instruments.

\section{F. The Procedure of Data Collection.}

In collecting the data, the researcher gave the test to the students: There were two kinds of test, namely written test and oral test.

1. Written test was done to measure students' grammar competency. There were 30 numbers of multiple choice test in 60 minutes about simple present tense for the sample class and there were four options a, b, c and d. The researcher used multiple choice test of positive, negative, and interrogative form sentence of simple present tense. The test itself was adopted from English Tenses and Grammar application by Nofta Studio in Google play store.

2. Oral test was done to measure students' speaking ability. The researcher gave some questions to 


\section{Datokarama English Education Journal Vol.2 No. 2, 2021}

the participants and the questions were about self-introduction and daily activity. This activity focused on their grammar and vocabulary rather than the other aspects of speaking.

\section{G. The Technique of Data Analysis.}

In this research, the researcher used Product Moment Correlation to analyze the data to know the result whether there is a correlation between two variables, and it was analyzed by using SPSS application version 26.

\section{Normality Test}

Normality test objectives are to determine whether a research data are normally distributed or not. In parametric statistical analysis, normally distributed data are a necessity as well as an absolute requirement that must be met. Meanwhile, if it is found that the data is not normally distributed, then the research hypothesis testing is used using a non-parametric statistical analysis approach. To detect the normality of a data, the researcher used the Shapiro Wilk technique. This technique is generally used for small samples (less than 50 data). Meanwhile, for a large sample size (more than 50 data), the normality test is carried out using the Kolmogorov Smirnov technique. The following is a theory about the basis for decision making in the Shapiro wilk normality test. According to Singgih Santoso, the data are said to be normally distributed (symmetrical) in the Shapiro Wilk test if the significant value is higher than $0.05 .^{8}$

\section{Linearity Test}

Linearity test intend to determine whether two variables have a significant linear relationship or not. A good correlation should have a linear

8 Singgih Santoso, Panduan Lengkap SPSS Versi 20 (Gramedia, 2014), 191. relationship between the independent variable ( $\mathrm{x}$ ) and the dependent variable (y).This test was used as a prerequisite for Pearson correlation analysis. Testing on SPSS was carried out by using the test for Linearity.

As for the basis for decision making in the linearity test, it can be done as follow:

\section{a. comparing the significant value with 0.05}

1) If the value of Deviation from Linearity is significant> 0.05 , then there is a significant linear relationship between the independent and dependent variables.

2) If the deviation from Linearity value is significant $<0.05$, then there is no significant linear relationship between the independent variable and the dependent variable. ${ }^{9}$

\section{The Hypothesis Test}

The hypothesis test was used to find out whether the null hypothesis (H0) or the alternative hypothesis (Ha) is accepted or not in this research. The most commonly used in the correlation procedure is the Pearson Product Moment and the researcher analyzed the data by using SPSS application version 26. Pearson product moment correlation was used to find out the direction and strength of the relationship between the independent variable (x) and the dependent variable (y). As for the guidelines or basis for decision making in this Pearson correlation analysis, it can be done as follows:

1) Based on the significance value (2tailed): if the significance value (2-

9 Rochmat Aldy Purnomo, Analisis Statistik Ekonomi Dan Bisnis Dengan SPSS (Ponorogo: Wade Group, 2016), 94-95. 


\section{Datokarama English Education Journal Vol.2 No. 2, 2021}

tailed) $<0.05$ then there is a correlation between the variable being linked. Conversely, if the significance value (2-tailed)> 0.05 , there is no correlation.

2) Based on the calculated $r$ value (Pearson correlations): if the value of $r$ count> $r$ table then there is a correlation between variables. Conversely, if the value of $r$ count $<r$ table, it means that there is no correlation between variable. ${ }^{10}$

The degree of correlation and the strength of the relationship can be classified as shown in the following table:

Table 3

Table of correlation level and relationship strength.

\begin{tabular}{|c|c|}
\hline $\begin{array}{c}\text { Correlation value } \\
(\mathbf{r})\end{array}$ & level of relationship \\
\hline $0,00-0,199$ & $\begin{array}{c}\text { Very low } \\
\text { correlation }\end{array}$ \\
\hline $0,20-0,399$ & Low correlation \\
\hline $0,40-0,599$ & $\begin{array}{c}\text { Average/enough } \\
\text { correlation }\end{array}$ \\
\hline $0,60-0,799$ & High correlation \\
\hline $0,80-0,100$ & Very high correlation ${ }^{11}$ \\
\hline
\end{tabular}
follows:

The hypothesis to be proved is as

1) Ha: If the significance value (2-tailed) is $<0.05$, the alternative hypothesis (Ha) is accepted and the null hypothesis is rejected. It means that there is acorrelation between grammar competency and speaking ability of the eighth grade students in SMPN 1 Palu in the academic year 2020/2021.

2) H0: If the significance value (2-tailed) is $>0.05$, the null hypothesis ( $\mathrm{H} 0)$ is accepted and the alternative hypothesis is rejected. It means that there is no correlation between

${ }^{10}$ Ibid., 137-142.

11 Imam Machali, Statistik Itu Mudah: Menggunakan SPSS Sebagai Alat Bantu Statistik (Yogyakarta: Ladang Kata, 2015), 103. grammar competency and speaking ability of the eighth grade students in SMPN 1 Palu in the academic year 2020/2021.

\section{RESULT AND DISCUSSION}

\section{A. The Description of Research Results}

This section will present the description of the research data regarding two variables, namely students' grammar competency and students' speaking ability. This research was done to find out whether there was a correlation between grammar competency and speaking ability of the eighth grade students in SMPN 1 Palu in academic year 2021/2022 with the total number of the sample was 31 students. The researcher gave two kinds of test to measure students' grammar competency and their speaking ability. The test itself was taken in 22 February until 10March 2021. During the implementation of each test itself, it was carried out by following the schedule of English subject in the class that was used as the research sample. The following are the results of the research for the two variables.

\section{The Result of Grammar Test}

Regarding grammar competency, the researcher gave multiple choices as written test that contained 30 numbers of questions in simple present tense form with some indicators such as the ability to identify the affirmative sentence, the ability to identify the negative sentence and the ability to identify the interrogative sentence. Each student only got one chance to answer the multiple choice questions, and they had 60 minutes to choose the best answer. Each number had one point, and for getting a score, the correct answer divided by 30 (maximum score) then multiplied by 100 (constant number). From the result of students' grammar scores, the researcher found the frequencies statistics as follows: 
Datokarama English Education Journal Vol.2 No. 2, 2021

Table 5

Table of Frequencies Statistics

\begin{tabular}{|lrr|}
\hline \multirow{2}{*}{ Grammar } & Statistics \\
N & Valid & 31 \\
\cline { 2 - 3 } & Missing & 0 \\
\hline Mean & 82.42 \\
\hline Median & 86.00 \\
Mode & 100 \\
\hline Std. Deviation & 13.817 \\
\hline Range & 50 \\
\hline Minimum & 50 \\
\hline Maximum & 100 \\
\hline Sum & 2555 \\
\hline
\end{tabular}

The table above shows that the $\mathrm{N}$ (numbers of respondents) is 31. Based on these 31 respondents, the smallest student's score (minimum) is 50 and the largest student's score (maximum) is 100.The value range is the difference between the minimum and maximum values which is 50 . Subsequently the sum value is the sum of the grammar scores of 31 students (respondents) which is 2555. The researcher found that the average value or mean of 31 respondents is 82.42 ; the median is 86.00 and the mode or the score that often being found is 100 with a standard deviation of 13.817 .

In order to understand the scores, frequency, and percentage of students' grammar competency, the researcher analyzed the data by using SPSS and listed them in the table below.

Table 6

Table of Frequencies Statistics

\begin{tabular}{|ll|r|r|r|r|}
\hline & & \multicolumn{4}{|c|}{ Grammar } \\
& & $\begin{array}{c}\text { Frequenc } \\
\mathrm{y}\end{array}$ & $\begin{array}{c}\text { Percen } \\
\mathrm{t}\end{array}$ & $\begin{array}{c}\text { Valid } \\
\text { Percen } \\
\mathrm{t}\end{array}$ & $\begin{array}{c}\text { Cumulativ } \\
\text { e Percent }\end{array}$ \\
\hline Vali & 50 & 1 & 3.2 & 3.2 & 3.2 \\
\cline { 2 - 6 } & 60 & 1 & 3.2 & 3.2 & 6.5 \\
\cline { 2 - 6 } & 63 & 2 & 6.5 & 6.5 & 12.9 \\
\hline 66 & 2 & 6.5 & 6.5 & 19.4 \\
\hline 70 & 1 & 3.2 & 3.2 & 22.6 \\
\hline 73 & 3 & 9.7 & 9.7 & 32.3 \\
& 76 & 1 & 3.2 & 3.2 & 35.5 \\
\hline & 80 & 2 & 6.5 & 6.5 & 41.9 \\
& 83 & 2 & 6.5 & 6.5 & 48.4 \\
\hline 86 & 3 & 9.7 & 9.7 & 58.1 \\
\hline
\end{tabular}

\begin{tabular}{|l|r|r|r|r|}
\hline 90 & 4 & 12.9 & 12.9 & 71.0 \\
\hline 93 & 2 & 6.5 & 6.5 & 77.4 \\
\hline 96 & 2 & 6.5 & 6.5 & 83.9 \\
\hline 100 & 5 & 16.1 & 16.1 & 100.0 \\
\hline $\begin{array}{l}\text { Tota } \\
1\end{array}$ & 31 & 100.0 & 100.0 & \\
\hline
\end{tabular}

After that, the researcher classified the students' grades according to Suharsimi Arikunto's grade classification to explain the students' achievement in grammar test. ${ }^{1}$

Table 7

\section{Classification of Students' Achievement}

\begin{tabular}{cccc}
\hline Value & $\begin{array}{c}\text { Level of } \\
\text { Achievement }\end{array}$ & Frequency & Percentage \\
\hline $80-$ & Very good & 20 & $64,7 \%$ \\
100 & Good & 7 & $22,6 \%$ \\
$66-79$ & Fair & 3 & $9,7 \%$ \\
$55-65$ & Poor & 1 & $3,2 \%$ \\
$40-55$ & Fail & & \\
$<39$ & & 31 & $100 \%$ \\
\hline \multicolumn{5}{c}{ Total } \\
\hline
\end{tabular}

Based on the data above, it shows that there is 1 student $(3,2 \%)$ in poor level, 3 students $(9,7 \%)$ in fair level, 7 students $(22,6 \%)$ in good level and 20 students $(64,7 \%)$ in very good level. It means that the students' achievement in grammar competency was very good due to the fact that there are 20 students who got 80-100 score.

\section{The Result of Speaking Test}

Based on the instrument of the test, the researcher gave oral test to measure students' speaking ability. The researcher gave each student time within 6 minutes to answer some questions. The topics of oral test itself were about self-introduction and daily activity. To determine the score of every student, the students' raw score was divided with maximum score (20) and then multiplied by constant number (100).

Suharsimi Arikunto, Dasar-Dasar Evaluasi Pendidikan (Jakarta: BumiAksara,2012),281. 


\section{Datokarama English Education Journal Vol.2 No. 2, 2021}

From the table of students' speaking scores, the researcher found the frequencies statistics as follows:

Table 9

Table of Frequencies Statistics

\begin{tabular}{|c|c|c|}
\hline & tatistics & \\
\hline $\begin{array}{l}\text { Speaking } \\
\mathrm{N}\end{array}$ & Valid & 31 \\
\hline & Missing & 0 \\
\hline Mean & & 53.71 \\
\hline Median & & 55.00 \\
\hline Mode & & 45 \\
\hline Std. Deviation & & 13.599 \\
\hline Range & & 55 \\
\hline Minimum & & 25 \\
\hline Maximum & & 80 \\
\hline Sum & & 1665 \\
\hline
\end{tabular}

The tables above shows the $\mathrm{N}$ (number of respondents) are 31. Based on these 31 respondents, the smallest student's score (minimum) is 25and the largest student's score (maximum) is 80.The value range is the difference between the minimum and maximum values which is 55 . Subsequently, the sum value is the sum of the grammar scores of 31 students (respondents) which is 1665 . The researcher found that the average value or mean of 31 respondents is 53.71, the median is 55.00 , and the mode or the score that often being found is 45 with a standard deviation of 13.599 .

In order to understand the scores, frequency, and percentage of students' speaking ability, the researcher analyzed the data by using SPSS and listed them in the table below.

Table 10

Table of Frequencies Statistics

\begin{tabular}{|c|c|c|c|c|c|}
\hline \multicolumn{6}{|c|}{ Speaking } \\
\hline 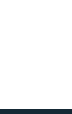 & 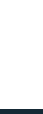 & $\begin{array}{c}\text { Frequenc } \\
\mathrm{y}\end{array}$ & $\begin{array}{c}\text { Percen } \\
t\end{array}$ & $\begin{array}{c}\text { Valid } \\
\text { Percen } \\
\mathrm{t}\end{array}$ & $\begin{array}{l}\text { Cumulativ } \\
\text { e Percent }\end{array}$ \\
\hline \multirow{9}{*}{$\begin{array}{l}\text { Vali } \\
\text { d }\end{array}$} & 25 & 1 & 3.2 & 3.2 & 3.2 \\
\hline & 30 & 1 & 3.2 & 3.2 & 6.5 \\
\hline & 35 & 1 & 3.2 & 3.2 & 9.7 \\
\hline & 40 & 3 & 9.7 & 9.7 & 19.4 \\
\hline & 45 & 5 & 16.1 & 16.1 & 35.5 \\
\hline & 50 & 4 & 12.9 & 12.9 & 48.4 \\
\hline & 55 & 4 & 12.9 & 12.9 & 61.3 \\
\hline & 60 & 4 & 12.9 & 12.9 & 74.2 \\
\hline & 65 & 2 & 6.5 & 6.5 & 80.6 \\
\hline
\end{tabular}

\begin{tabular}{|l|r|r|r|r|}
\hline 70 & 3 & 9.7 & 9.7 & 90.3 \\
\hline 75 & 2 & 6.5 & 6.5 & 96.8 \\
\hline 80 & 1 & 3.2 & 3.2 & 100.0 \\
\hline $\begin{array}{l}\text { Tota } \\
1\end{array}$ & 31 & 100.0 & 100.0 & \\
\hline
\end{tabular}

After that, the researcher classified the students' grades according to Suharsimi Arikunto's grade classification to explain the students' achievement in speaking test. $^{2}$

Table 11

Classification of Students' Achievement

\begin{tabular}{cccc}
\hline Value & $\begin{array}{c}\text { Level of } \\
\text { Achievement }\end{array}$ & Frequency & Percentage \\
\hline $80-$ & Very good & 1 & $3,2 \%$ \\
100 & Good & 5 & $16,2 \%$ \\
$66-79$ & Fair & 10 & $32,3 \%$ \\
$55-65$ & Poor & 12 & $38,7 \%$ \\
$40-55$ & Fail & 3 & $9,6 \%$ \\
$<39$ & & 31 & $100 \%$ \\
\hline \multicolumn{4}{c}{ Total } \\
\hline \multicolumn{3}{c}{ Based on the data above, it shows }
\end{tabular}

that there are 3 students $(9,6 \%)$ in fail level, 12 students $(38,7 \%)$ in poor level, 10 students $(32,3 \%)$ in fair level and then 5 students $(16,2 \%)$ in good level and then 1 student in very good level. It means that the students' achievement in speaking ability was fair due to the fact that there are 16 students who got 55-100 score.

3. The Result of Data Analysis

a. Result of normality of the data

Data normality test was used to find out whether the data is normally distributed or not. From the result, it is known that the df (degree of freedom) value for data from grammar is 31 and speaking is 31 . It means the number of data samples for each variable is less than 50. So that the use of the Saphiro Wilk technique is to detect data normality in this research can be said right.

From the table test of normality, it is known that a significant value for grammar data is 0.083 and a significant value for speaking data is 0.827. Because the significant value for both data is $>0.05$, as the basis for decision making in the

${ }^{2}$ Ibid., 281. 


\section{Datokarama English Education Journal Vol.2 No. 2, 2021}

Shapiro Wilk normality test that has been described, it can be concluded that the data on the grammar and speaking variables were normally distributed.

\section{b. Result of linearity test}

To calculate the value of linearity, the researcher used SPSS 26 for windows. It is obtained that a significant deviation from linearity value was $0.194>0.05$. It can be concluded that there was a significant linear relationship between the grammar competency variable $(\mathrm{x})$ and the speaking ability variable (y).

\section{c. Result of hypothesis test}

When the data is normally distributed and there is a significant linear relationship then the data was processed by using SPSS program to determine the correlation coefficient, so that it can be explained how the relationship between grammar competency and speaking ability is.

Based on the significance (2-tailed), it is known the sig. (2 tailed) between grammar competency $(\mathrm{x})$ and speaking ability (y) is $0.023<0.05$, then $\mathrm{Ha}$ is accepted and Ho is rejected. So it can be concluded that there is a significant correlation between the grammar competency variable and the speaking ability variable. When viewed from the calculation results, the correlation between variables "Grammar competency" and "speaking ability" showed a number of 0.407 . This figure indicates an average or enough correlation and unidirectional. This means if the grammar variable is high then the speaking variable will be higher too.

\section{B. The Discussion of Research Results}

After the researcher performed a correlation analysis using the SPSS program, the correlation coefficient and significance value was obtained. The correlation coefficient was used to determine the closeness of the relationship and the direction of the relationship, while the significance value was used to determine whether the relationship is meaningful or not.

The problem to be addressed in this research was whether there is a correlation between students' grammar competency and students' speaking ability. The result was got from collecting and analyzing the data, the data took from test by using Product Moment Correlation in SPSS application. There were two types of test used in this research. They were grammar competency test and speaking ability test. They were used because to know the correlation of students' grammar competency and their speaking ability. After conducting tests to collect value data from variables $\mathrm{X}$ and $\mathrm{Y}$, the researcher then carried out tests for normality and linearity to see whether the data is normally distributed and there is a linear relationship or not. This step was taken as a prerequisite for conducting a correlation test using the Pearson product moment correlation on the SPSS program.

Based on data analysis, it was known that a significant value for grammar data is 0.083 and a significant value for speaking data is 0.827 . Both of the data was higher than 0.05. It means that the data from grammar and speaking were normally distributed then the grammar and speaking data also have a linear relationship where a significant deviation from linearity value is $0.194>0.05$. It means that there was a significant linear relationship between the grammar competency and the speaking ability.

Based on the results of the research data analysis, there was a positive and significant correlation between the students' grammar competency and the students' speaking ability at the eighth grade students in SMPN 1 Palu. The results of the correlation analysis between the grammar competency variable and the speaking ability showed a positive correlation of0.407 with a significance level of $5 \%$. This means that the correlation coefficient according to Imam 


\section{Datokarama English Education Journal Vol.2 No. 2, 2021}

Machali was in the moderate or sufficient direction namely $0.40-0.599 .{ }^{3}$ With the results of this positive correlation it can be stated that the higher students' grammar competency, the higher their speaking ability and vice versa, the lower the students' grammar competency, the lower their speaking ability.

Based on the results of the correlation analysis between the students' grammar competency and the students' speaking ability, the $\mathrm{r}$ value was obtained at 0.407 with $\mathrm{p}=0.023(\mathrm{p}<0.05)$ indicating that there was a significant positive relationship between students' grammar competency and students' speaking ability. This supports the alternative hypothesis to be accepted. As the answer of formulation of the research, it can be concluded that there is a correlation between grammar competency and speaking ability at the eighth grade students of SMPN 1 Palu in the academic year of 2020/2021.

\section{CONCLUSION AND SUGGESTION A. Conclusion}

There is a positive and significant correlation between students' grammar competency and their speaking ability of the eighth grade students at SMPN 1 Palu in the academic year 2020/2021. It was revealed from the result of significance value was $0.023<0.05$ that suggests the alternative hypothesis is accepted while the null hypothesis is rejected. The computation also showed that the $r$ counted was higher than $r$ table, it was $0.407>0.355$.It also indicates that the correlation level between students' grammar competency and their speaking ability is average or moderate correlation.

Through the analysis of the data, the test of hypothesis and the discussion in the previous chapter, it is concluded that the

\footnotetext{
3 Imam Machali, Statistik Itu Mudah: Menggunakan SPSS Sebagai Alat Bantu Statistik(Yogyakarta: Ladang Kata, 2015), 103.
}

grammar competencydoes contribute in speaking ability of the eighth grade students in SMPN 1 Palu. Even though the mean score of students' grammar competency was 82.42 while the mean score of students speaking ability was 53.71. But in this case, there is no relation between the mean value in determining the correlation. The correlation is calculated more to the value of each individual. Although the mean value of grammar test was 82.42 and it is much different from the mean value of speaking test which was 53.71. However, in correlation the calculated of $r$ counted showed that there is a correlation between grammar competency and speaking ability. It means that grammar competency does contribute in students' speaking ability but it does not mean thatstudents who get good score in grammar competency also get good score in speaking ability.There are other factors that can determine students' achievement inspeaking test, the students got low score in speaking because of their anxiety and they did not feel confident in conveying their ideas. As a result, it influenced their speaking ability. Furthermore, the researcher assumes that the students' speaking score can be lower than their grammar score because in speaking test the researcher focused only on their aspect of grammar and vocabulary, while there are other aspects such as comprehensions, pronunciation, and fluency. However, based on the result of $r$ value it is still can be interpreted that grammar competency helps to improve students speaking ability. Accordingly, the researcher concludes that grammar competency has a correlation in speaking ability.

\section{B. Suggestion}

\section{For The Teachers}

As a motivator, the English teacher can explain grammar rules well and improve students' understanding of grammar. As teachers, they must explain to students that in order to communicate 
Datokarama English Education Journal Vol.2 No. 2, 2021

effectively and clearly in an effective way, students must study grammar surely.

2. For Students

For students, the mastery of grammar is very important because it can be said effectively and clearly. Grammar is one of the language components that are relate with other components. Thus, the students are recommended to improve their grammar competency.

3. For the Subsequent Researcher

This research can contribute to educational research, it looks for the relationship between the two variables of grammar and speaking. This research may also relate to previous research that other researchers can use to further learn between language skills and language components. 
Datokarama English Education Journal Vol.2 No. 2, 2021

\section{References}

Abbaspour,Faezeh. Speaking Competency and Its Components : A Review of Literature, 2016.

Arikunto, Suharsimi. Dasar-Dasar Evaluasi Pendidikan. Jakarta: BumiAksara, 2012

Arlyansi, Yolanda. "The Correlation Between English Grammar Competency and Speaking Skill of The Eleventh Grade Students at Senior High School 1 Teluk Kuantan". English Education Department, State Islamic University of Sultan Syarif Kasim Riau, PekanBaru, 2018.

Asmawati, Nur. "Model of English Learning Based on Collaborative Theory to Improve Indonesian' Spoken Communication Ability". Makassar: Eternal (English, Teaching, Learning, and Research Journal), 2018.

Baker, Joanna and Heather Westrup.Essential Speaking Skills: A handbook for English Language Teachers.New York: Continuum, 2003.

Barrass, Robert. Speaking for yourself. New York: Routledge, 2006.

Bashir, Marriam. Factor Effecting Students' English Speaking Skills. British Journal Publishing, http://www.bjournal.co.uk/BJASS. aspx/2011/Factor Effecting Students' English Speaking Skills, 2011 .

Brown, Goold. The Grammar of English Grammars. Project Gutenberg, 2004.
.Principles of Language Learning and Teaching (3rd Ed). Englewood Cliffs: Prentice Hall, 2001.

- Teaching by Principle: An Interactive Approach to Language Pedagogy. New York: Longman, 2001.

.Teaching by Principles an Interactive Approach to Language Learners. New York: Addison Wesley Longman, 2001.

.Principles of Language Learning and Teaching(4th Ed). San Francisco: Addison Wesley Longman, 2004.

Chomsky, Noam. Aspects of the Theory of Syntax. Cambridge: MIT Press, 1965.

Cuellar, Marco Tulio Artunduaga. Process Writing and the Development of Grammatical Competency. How Journal, 2013.

D, Efrizal. 'Improving Students' Speaking through Communicative Language Teaching Method at Mts Ja-alhaq, Sentot Ali Basa Islamic Boarding School of Bengkulu, Indonesia". Bengkulu: State Institute of Islamic Studies (IAIN), 2012.

E, Susanti and Amri, Z. "Speaking Board Game to Teach Speaking of Descriptive Text (Paper)". Padang: Universitas Negeri Padang, 2013.

Hidayat, Wahyu and Nur Asmawati Lawahid. Metode Fuzzy Delphi Untuk Penelitian Sosial. Bandung: Alfabeta, 2020.

Hughes, Arthur.Testing for Language Teachers (Second Ed). Cambridge: Cambridge University Press, 2003. 


\section{Datokarama English Education Journal Vol.2 No. 2, 2021}

Islamiati, Dian."The Correlation between Students' Grammar Knowledge and Their Speaking Ability".English Education, Swadaya Gunung Jati University, Cirebon.

J. W,Cresswell. Educational Research: Planning, Conducting and Evaluating Quantitative and Qualitative Research. New Jersey: Pearson Education, 2008.

Jack, Richards and M Richards.Teaching Listening and Speaking from Theory to Practice. New York: Cambridge University Press, 2008.

Khotari, C.R. Research Methodology : Methods and Techniques. New Delhi: New Age International (P) Ltd, 2004.

Kurniawan, Erwin Hari. Basic English Grammar. Kediri: SMA3 Press, 2010.

Lock, Graham. Functional English Grammar: an Introduction for Second Language Teachers. Cambridge: Cambridge University Press, 1997.

Machali, Imam. Statistik Itu Mudah. Yogyakarta: Ladang Kata, 2015.

Maxom, Michelle. Teaching English as a Foreign Language for Dummies. Chichester: John Wiley and Sons, Ltd, 2009.

Nassaji, Hossien and Sandra Fotos.Teaching ESL/EFL : listening and speaking. New York: Routledge, 2009.

Nunan, David. Language Teaching Methodology. Cambridge: Cambridge University Press, 1991.
.Practical English Language Teaching $\left(1^{\text {st }}\right.$ Ed). USA: Mc Graw Hill, 2003.

- Practical English Language Teaching Grammar. New York: McGrawHill, 2004.

Priyanto, Agus and Lies Amin L. "The Correlation Between English Grammar Competency and Speaking Fluency of Eleventh Grade Students in SMAN 1 Sidoarjo“. English Education: Surabaya State University.

Purnomo, Rochmat Aldy.Analisis Statistik Ekonomi Dan Bisnis Dengan SPSS. Ponorogo: Wade Group, 2016.

Purpura, James. Assessing Grammar. Cambridge: Cambridge University Press, 2004.

Rahman, Anwar and Rafista Deviyanti "The Correlation Between Student's Motivation and Their English Speaking Ability “.Jurnal ilmiah esai , Vol 6, No 1, January 2012.

Ravid, Ruth. Practical Statistic for Educators (4thed). Plymouth: Rowman and Littlefield, 2011.

Santoso, Singgih.Panduan Lengkap SPSS Versi 20. Gramedia, 2014.

Scarcella,Robin C. \& Rebecca L. Oxford, The tapestry of language learning: The individual in the communicative classroom. Boston, MA: Heinle \& Heinle, 1992.

Silfani. "The Correlation between Students' Speaking Ability and the Mastery of Grammar at the Eleventh Grade Students of SMA Kristen Barana". English Education Study Program: Christian University of Indonesia Toraja. 
Datokarama English Education Journal Vol.2 No. 2, 2021

Sujarweni, V. Wiratna. SPSS Untuk Penelitian. Yoyakarta: Pustaka Baru Press, 2014.

Thornbury, Scott. How to Teach Grammar. Edinburgh: Pearson education limited, 1999.

Wang, Shengmei. "The Significance of English Grammar to Middle School Students in China". Finland: Academy Publisher, 2010.

Widiyanto, Joko.SPSS for Windows. Badan Penerbit FKIP-UMS, 2012. 